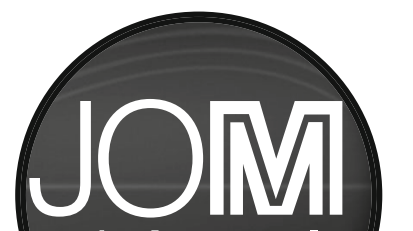

thejournal

\title{
2015 editorial calendar
}

\section{March 2015}

Theme: Additive Manufacturing

- Metal Powder for Additive Manufacturing (3D Printing)

- Progress in Additive Manufacturing

Manuscripts Due: Deadline Passed

\section{April 2015}

Theme: Biomaterials and Thin Films

- Nanomechanical Behavior of Biomaterials

- Surfaces and Biointerfaces

- Electronic, Biological, and Functional Thin Films

Manuscripts Due: Deadline Passed

\section{May 2015}

Theme: Metallurgy and Processing

- Aluminum: Shaping and Forming

- Friction Stir Welding and Processing

- Metallurgy: Energy and Environmental Issues

Manuscripts Due: Deadline Passed

\section{June 2015}

\section{Theme: Metals and Alloys}

- Beta-Titanium Alloys

- Permanent Magnets Beyond Nd-Dy-Fe-B

- Critical Materials: Strategies for Achieving Sustainability

- TMS2015 Bladesmithing Project

- In-Situ Mechanical Testing in Electron Microscopes: Part I

Manuscripts Due: February 15, 2015

\section{July 2015}

\section{Theme: Interfaces and Surface Engineering}

- Control of Interfacial Phenomena During Processing:

Modeling and Technology Developments

- Effects of Interfaces on Mechanical Properties of Composites

- Surface Engineering for Extreme Conditions

- Archaeomaterials

Manuscripts Due: March 15, 2015

\section{August 2015}

Theme: Advanced Modeling and Characterization

- ICME: Bridging Interfaces

- In-Situ Mechanical Testing in Electron Microscopes: Part II

- Advances in Modeling of Solidification Microstructures

- New Horizons in Mechanical Spectroscopy

- Dynamic Probing of Microstructure Evolution in Nanostructured Materials

- CALPHAD-Based ICME Research for Materials Geonomic Design

Manuscripts Due: April 15, 2015

\section{September 2015}

\section{Theme: Energy and Environment}

- Sustainability in Metallurgy

- Materials for Solar Applications

- Lead and Zinc Metallurgy

- Energy Materials: Synthesis, Characterization, and Applications

- Aluminum: Recycling and Environmental Issues

Manuscripts Due: May 15, 2015

October 2015

Theme: Physical Metallurgy

- Phase Transformations and Microstructural Evolution

- Progress in High-Entropy Alloys

- Progress with Lead-Free Solders

- Age-Hardenable Microalloying in Magnesium

Manuscripts Due: June 15, 2015

\section{November 2015}

Theme: Materials for Energy and Extreme Environments

- Materials Degradation in Light-Water Reactors

- Optimizing Energy in Industrial Furnaces

- High-Temperature Corrosion of Ni-Base Alloys

- Advances in Refractory Metals

Manuscripts Due: July 15, 2015

\section{December 2015}

Theme: Materials: Past, Present, and Future

- Stability of Materials

- Futuristic Nanomaterials and Composites

- Nanomechanical Measurements in Harsh Environments

- Aluminum: Cast Shop and Alloys

- Archaeomaterials

Manuscripts Due: August 15, 2015 


\section{5 advisors and committees}

Amit Pandey

Advanced Characterization, Testing, and Simulation Committee

Michael Gao

Alloy Phases Committee

Alton Tabereaux

Aluminum Committee

Candan Tamerler-Behar

Biomaterials Committee

Michael J. Demkowicz

Chemistry and Physics of Materials

Committee

Muralidharan Paramsothy

Composite Materials Committee

Bala Radhakrishnan

Computational Materials Science and

Engineering Committee

Vilupanur A. Ravi and

Kinga Unocic

Corrosion \& Environmental Effects

Committee

Babak Arfaei

Electronic Packaging and

Interconnection Materials Committee

Geoff Brooks

Energy Committee

Xiaochuan Lu

Energy Conversion and Storage

Committee
Chantal Sudbrack and

Mark Hardy

High Temperature Alloys Committee

Harald Oosterhof

Hydrometallurgy and Electrometallurgy Committee

Nitin Chopra

ICME Committee

James Saal

Magnesium Committee

Satoshi Hirosawa

Magnetic Materials Committee

Bowen Li

Materials Characterization

Committee

Marian S. Kennedy

Mechanical Behavior of Materials

Committee

Terry Xu and Jung-Kun Lee

Nanomaterials Committee

Jian Wang, Xiaodong Li, and Peter Hosemann

Nanomechanical Materials Behavior

Committee

Ramprashad Prabhakaran

Nuclear Materials Committee

Amy Clarke

Phase Transformations

Committee
Ma Qian

Powder Materials Committee

Antoine Allanore and

Ed Herderick

Process Technology and Modeling

Committee

Zhiwei Peng and

Dean Gregurek

Pyrometallurgy Committee

Gabrielle Gaustad

Recycling and Environmental

Technologies Committee

Todd Leonhardt

Refractory Metals Committee

Yuri Hovanski

Shaping and Forming Committee

Mohsen Asle Zaeem

Solidification Committee

Sandip Harimkar and

Srinivasa Bakshi

Surface Engineering Committee

Roger Narayan

Thin Films and Interfaces

Committee

William Joost

Titanium Committee

Anyone wishing to publish in JOM should follow the guidelines established in the JOM Instructions for Authors, which features detailed information on communication, manuscript preparation, and publication procedures. The Instructions for Authors are available on the JOM website at www.jom.tms.org.

For More Information Contact:

Telephone: (724) 776-9000 ext. 228

e-mail: jom@tms.org 